\title{
Another wrinkle in patchwork of US environmental release
}

\section{Washington}

YET another layer of complexity will be added to the current regulatory patchwork governing the environmental release of recombinant organisms if plans at the US Environmental Protection Agency (EPA) come to fruition. Last week, the EPA's biotechnology science advisory committee voted to go forward with a scheme to institute a network of review committees - to be named 'environmental biosafety committees' - for the purpose of approving field tests of genetically altered organisms.

The issues of what constitutes an environmental release and at what point research involving recombinant organisms falls under the EPA's regulations have been murky. The incident last summer when Montana State University researcher Gary Strobel injected elm trees with a recombinant bacteria without EPA approval (see Nature 328, 659 \& 329, 95; 1987) emphasized the fact that these issues required clarification. EPA is now in the process of extending its Toxic Substances Control Act to cover research and development work, and the environmental biosafety committees would oversee the application of this statute in biotechnology research settings.

EPA plans to model its environmental biosafety committees on the institutional biosafety committees, administered by the US National Institutes of Health (NIH) Recombinant Advisory Committee, that review all recombinant DNA experiments. There is wide agreement that the institutional biosafety committees have been a good way to control recombinant DNA experimentation without

\section{Dutch field trials}

\section{Waalre, The Netherlands}

FIELD trials of genetically modified plants are expected to be carried out for the first time in the Netherlands this year. The biotechnology company Mogen International has succeeded in inserting a foreign gene into potato plants conferring resistance to viral infection, although the identity of the gene and the disease have not been disclosed. The ad hoc Committee on Recombinant DNA has recommended approval of field trials, and official permission from the community of Dronten, where the trials are to be carried out, is expected to be a formality.

Permanent legal rules for field tests with genetically modified organisms are expected to be incorporated in the law for environmentally dangerous substances later in 1988. being unduly restrictive. As outlined, the EPA plan calls for setting up committees of five people - three scientists with expertise in areas of microbial or plant ecology and two representatives from the local community - at each university or company that would field-test recombinant organisms. The EPA's committees would differ from the NIH biosafety committees in that they would be backed up by regulatory statutes and infringers could be prosecuted.

The case-by-case review of proposed experiments by the environmental biosafety committees would also include the solicitation of public comment on the field test, and the committee would be responsible for addressing questions from the local community. The survey of attitudes toward biotechnology sponsored by Congress last year (see Nature 327, 453; 1987) showed that the public had confidence in university scientists' assessment of environmental risks. But the survey was completed before the Gary Strobel 'incident', and it is not clear whether that confidence still holds.

The environmental biosafety committee concept is likely to stir opposition from industry and university researchers, who are already confused by the federal maze of regulations governing biotechnology. Henry Miller, the biotechnology adviser to the US Food and Drug Administration, says EPA's plan to set up environmental biosafety committees "puts the cart before the horse", because the pivotal issue is deciding which experiments should be subject to review. Once this is ironed out, he reasons, there is no need for the additional bureaucracy that the review committees would certainly add.

William Gartland, the director of the recombinant DNA activities office at NIH, wonders whether the NIH institutional biosafety committees already in place would not be sufficient to review field release experiments, particularly at institutions already heavily involved in recombinant work. The chairman of the institutional biosafety committee at Montana State University, Clifford Bond, says he would "hate to see more committees" because it is the "worst way to get anything accomplished". But he concedes that it "certainly helps to have a hammer" of firm regulations to drop on those who would break the rules.

EPA is devoting increased staff time to working out the details of how the environmental biosafety commitees would function, and the rules for establishing the committees is expected in the spring.

\section{Health risks of radon are given a new look}

\section{Washington}

How much does environmental exposure to radon and its alpha-emitting daughters contribute to lung cancer in humans? This question has received renewed attention recently with the realization that radon exposure can be relatively high in homes in certain parts of the United States. In a report released last week, a committee of the National Research Council proposes new estimates of the risk, concluding that the effects of radon exposure vary not only with dose, but also with time since exposure and with age

To reach the new estimates, the research council's committee on the biological effects of ionizing radiation used statistical regression techniques to evaluate data from four studies of radonexposed miners. The committee found that risk of lung cancer attributable to radon reduces with age. The analysis also revealed that exposure within the previous fifteen years was a better predictor of risk than any earlier exposure. Cigarette smoking appeared to interact with radon exposure in a multiplicative rather than additive manner in increasing the risk of lung cancer. The committee urged therefore that more data be collected on the smoking habits of miners exposed to radon.

In evaluating cumulative radon exposure, the committee used the working level month (WLM) which is defined as exposure to approximately $100 \mathrm{pCi}$ of radon per litre of air in $\mathbf{1 7 0}$ hours, a time period chosen for historical reasons. Occupational exposure to 4 WLM, approximately the number of hours in one month, would increase lung cancer risk by 60 per cent for the general population for people between 20 and 40 years old. The greatest increased risk is to smokers, who are at ten times higher risk than non-smokers.

Polonium, radium, thorium and uranium are also alpha-emitters presenting health risks, as are the transuranic elements. Cancer risk from environmental exposure to the naturally occurring elements is relatively low. Epidemiological studies of exposure to the transuranic elements does not provide sufficient data for risk estimates.

Joseph Palca

Health risks of radon and other internally deposited alpha emitters. (National Academy Press, Washington, DC 1988.)

\section{AIDS Commission: Correction}

THE chairman of the US Presidential Commission on the HIV epidemic is retired admiral James D. Watkins, not James D. Watson (see Nature 330, 687; 1987). 